DARIUSZ STĘPKOWSKI

Wydział Nauk Pedagogicznych

Uniwersytet Kardynała Stefana Wyszyńskiego

Warszawa

STANISLAV IVANOV

Institut für Bildungsmonitoring und Qualitätsentwicklung

Hamburg (Niemcy)

ANNA KSIONEK

Warszawa
Forum Pedagogiczne

2016/2 cz. 1

Wpłynęło: 12.04.2016

Zatwierdzono do druku: 24.05.2016

DOI: $10.21697 / \mathrm{fp} .2016 .2 .03$

\title{
ETIK-INTERNATIONAL WARSZAWA. HISTORIA BADANIA, PROBLEMY BADAWCZE I ANALIZA WYNIKÓW ${ }^{1}$
}

Streszczenie: Głównym zamierzeniem badania ETiK-International przeprowadzonego w 2014 roku w wybranych gimnazjach Warszawy i województwa mazowieckiego było sprawdzenie, czy i w jakim stopniu lekcje etyki stanowią odrębną domenę szkolnego nauczania i uczenia się oraz jakie wyniki osiągają w tym przedmiocie polscy uczniowie w porównaniu $\mathrm{z}$ ich niemieckimi i austriackimi rówieśnikami. Niestety, nie udało się w pełni zrealizować tego zamierzenia badawczego.

Artykuł składa się z trzech rozdziałów. W pierwszym zostanie zrekonstruowany powrót lekcji religii do szkół publicznych w Polsce i związane z nim ustanowienie etyki przedmiotem alternatywnym. Następnie omówione zostaną bezowocne starania o przeprowadzenie ogólnopolskiego badania ETiK. Na zakończenie zaś, w trzecim rozdziale, zostanie scharakteryzowane wspomniane na wstępie badanie ETiK-International, ze szczególnym uwzględnieniem zastosowanego w nim narzędzia, podjętych problemów badawczych i uzyskanych wyników.

Słowa kluczowe: lekcje etyki, kompetencja moralno-etyczna, badania pedagogiczne.

Mimo że wychowanie moralne w Polsce stanowi przedmiot nieustannych rozważań pedagogicznych (Suchodolski 1961; Muszyński 1974; Kotłowski 1976; Marek 2005; Łobocki 2008; Horowski 2015), zaskakuje fakt, że nauczanie w tym zakresie nie było przedmiotem takich samych analiz - przynajmniej do tej pory. Wskutek tego

1 Tekst został opublikowany w języku niemieckim pt. ETiK-International-Warschau. Ethik-und Religionsunterricht in Polen. Forschungsfragen, Ansatz und Befunde der Validierungsstudie w: Benner, Nikolova 2016, s. 202-216. 
w kontekście pedagogicznym nie używa się w odniesieniu do moralności terminu „nauczanie”, lecz raczej „wychowanie”, co ma podkreślać jego nieedukacyjny charakter (Stępkowski 2015a).

Poniżej zrekonstruowano wysiłki zmierzające do przeprowadzenia w Polsce badania podobnego do tego, jakie odbyło się w Berlinie w ramach projektu ETiK. W pierwszym rozdziale zostanie zrekonstruowany powrót lekcji religii do szkół publicznych w Polsce, któremu towarzyszyło ustanowienie etyki przedmiotem alternatywnym wobec religii. Następnie omówione zostaną zakończone niepowodzeniem starania o przeprowadzenie ogólnopolskiego badania kompetencji moralno-etycznej. W trzecim i ostatnim rozdziale zostanie przedstawiony przebieg i wyniki badania ETiK-International, które przeprowadzono w 2014 roku w wybranych 15 gimnazjach Warszawy i województwa mazowieckiego.

\section{Etyka i religia jako przedmioty szkolne}

Lekcje religii znalazły się ponownie w szkołach publicznych w Polsce jako „Zwyczajny” przedmiot nauczania po przełomie politycznym, jaki dokonał się w 1989 roku. Zainicjowana wówczas transformacja objęła wszystkie sfery życia, w tym również edukację. Symbolicznym wyrazem tego był powrót z dniem 1 września 1990 roku religii do szkół. Ta sama data stanowi początek obecności etyki w szkolnych planach nauczania. Etyka znalazła się w nich jako przedmiot alternatywny z myślą o uczniach, którzy nie będą uczęszczać na zajęcia z religii. Tak właśnie wynika w Instrukcji Ministra Edukacji Narodowej z dnia 3 sierpnia 1990 roku w sprawie nauczania religii w szkołach publicznych, gdzie w pkt 2 stwierdza się: „Uczniowie, których rodzice nie życzą sobie ich religijnego wychowania, nie mają obowiązku uczęszczania na lekcje religii w szkole. Dla nich w miarę możliwości szkoła powinna zorganizować lekcje, których celem byłoby poznanie zasad etycznych lub inne zajęcia, a w każdym przypadku zapewnić odpowiednią opiekę i bezpieczeństwo" (cyt. za: Zieliński 2014, s. 95-96). Podobne słowa padają w wydanej trzy tygodnie później instrukcji Ministra Edukacji Narodowej z dnia 24 sierpnia 1990 roku, a mianowicie: „Dla uczniów w ogóle niekorzystających z lekcji religii w miarę możliwości szkoła powinna zorganizować lekcje, których celem byłoby poznanie uniwersalnych zasad etycznych, a także norm współżycia osób i grup o różnych wyznaniach i światopoglądach oraz różnej narodowości” (cyt. za: Zieliński 2014, s. 96). Pomijając wątek wychowania do interreligijności i interkulturowości, który niespodziewanie pojawia się w drugim dokumencie, wyraźnie da się zauważyć, że w obu instrukcjach etyce powierza się rolę substytutu religii ${ }^{2}$. W obu też używa się zwrotu: „W miarę możliwości”. Odnośnie do tej ostatniej sprawy Tadeusz J. Zieliński twierdzi: „Stwierdzenie

2 To, że ersatzem dla lekcji religii ma być etyka, wynika właściwie z jednego tylko aktu prawnego, a mianowicie z Rozporządzenia Ministra Edukacji Narodowej z dnia 14 kwietnia 1992 roku 
to jest znamienne, gdyż wskazuje na charakter stosunku władz publicznych do zajęć organizowanych dla osób niekorzystających z nauki religii" (Zieliński 2014, s. 96). Ten stosunek trafnie oddaje wyrażenie „edukacyjny pozór”, którym posłużyła się Teresa Hejnicka-Bezwińska dla opisania dominującego w dziejach powojennej oświaty polskiej zjawiska pseudoedukacji (Hejnicka-Bezwińska 2015). W odniesieniu do wprowadzonych na początku lat 9o. minionego stulecia lekcji etyki zjawisko to polegało zarówno na tym, że w pierwszych dwóch dekadach w szkołach zazwyczaj w ogóle ich nie organizowano, jak również na tym, że aż dotąd nie opracowano w zadowalający sposób podstaw programowych nauczania etyki (Piast-Szlubowski 2015).

Zaprogramowany odgórnie spór między lekcjami etyki a religii od początku budził wątpliwości. Trybunał Konstytucyjny w wyroku z 20 kwietnia 1993 roku uznał dopuszczalność traktowania etyki jako przedmiotu alternatywnego wobec religii, podkreślając przy tym, że ta ostatnia ma charakter dobrowolny (Orzeczenie z dnia 20 kwietnia 1993 roku). Z tego wynikało, że uczniowie mogli zrezygnować z lekcji religii bez konieczności uczęszczania na etykę. W tym samym wyroku podkreślono równocześnie prawo uczniów do pobierania nauki zarówno religii, jak i etyki. W codzienności szkolnej zaczęły więc współistnieć różnorodne modele łączenia obu tych przedmiotów - od takiego, w którym etyka zastępowała religię, przez równoczesne nauczanie obu tych przedmiotów, aż po model, w którym uczniowie po wypisaniu się z religii nie uczęszczali ani na etykę, ani na żadne inne zajęcia. Zmianę w tej dość chaotycznej sytuacji spowodował inny proces sądowy, który wpłynął zasadniczo na aktualny status prawny nie tylko etyki, lecz również religii w Polsce.

Otóż w 2010 roku zapadł przed Europejskim Trybunałem Praw Człowieka wyrok w sprawie Grzelak przeciwko Polsce. Skarżący Czesław i Urszula Grzelakowie (rodzice) zaskarżyli stan, w którym ich syn Mateusz został zgodnie z ich życzeniem wypisany z lekcji religii w szkole podstawowej, ale nie miał możliwości uczęszczania na zajęcia alternatywne (np. z etyki). W czasie, kiedy inne dzieci uczestniczyły w lekcjach religii, Mateusz musiał przebywać w bibliotece szkolnej lub w sąsiednim pokoju. Oprócz tego przedmiotem skargi było to, że syn państwa Grzelaków dwukrotnie zmieniał szkołę, gdyż „poddawany był dyskryminacji oraz fizycznym i psychicznym prześladowaniom ze strony innych uczniów z powodu nieuczestniczenia w lekcjach religii" (Sprawa Grzelak przeciwko Polsce, s. 3). Poinformowane o tym władze oświatowe przekazały rodzicom wiadomość, że w ich okręgu szkolnym żadna ze szkół nie prowadzi zajęć z etyki. Należy nadmienić, że w świetle obowiązującego wówczas rozporządzenia Ministra Edukacji Narodowej minimalna liczba uczniów, od której spoczywał na kierownictwie szkoły obowiązek

(Dz. U. Nr 36, poz. 155 z późn. zm.). Do dziś jest to jedyna prawna legitymizacja obecności etyki w szkołach publicznych. 
przygotowania zajęć z etyki, wynosiła siedem (Rozporządzenie Ministra Edukacji Narodowej z dnia 14 kwietnia 1992 roku, par. 2).

Europejski Trybunał Praw Człowieka uznał, że brak dostępu do lekcji etyki w polskich szkołach jest naruszeniem wolności wyznania i zakazu dyskryminacji. $\mathrm{Na}$ tej podstawie zobowiązał rząd polski do wprowadzenia stosownych zmian (Sprawa Grzelak przeciwko Polsce, s. 23). W związku z wykonaniem wyroku w sprawie Grzelak przeciwko Polsce Ministerstwo Edukacji Narodowej wdrożyło szereg działań mających na celu zagwarantowanie zainteresowanym uczniom realnego dostępu do lekcji etyki. Za najważniejsze należy uznać wydanie Rozporządzenia Ministra Edukacji Narodowej z dnia 25 marca 2014 roku, które weszło w życie w dniu 1 września tego samego roku. W dokumencie tym stwierdza się, że każdy uczeń - choćby tylko jeden - musi mieć możliwość uczestniczenia w lekcjach etyki. Równocześnie jednak uzależniono organizację, ale już nie tylko lekcji etyki, lecz również religii, od złożenia pisemnego oświadczenia o chęci uczestniczenia w tych zajęciach. W przypadku uczniów niepełnoletnich do złożenia takiego oświadczenia uprawnionymi osobami są rodzice, uczniowie zaś pełnoletni mogą składać je we własnym imieniu. Oświadczenie nie musi być składane co roku, może jednak w każdej chwili zostać zmienione (Rozporządzenie Ministra Edukacji Narodowej $\mathrm{z}$ dnia 25 marca 2014 roku).

W związku z powyższym w dniu 5 czerwca 2014 roku Komitet Ministrów Rady Europy przyjął rezolucję uznającą wykonanie przez rząd polski wyroku Europejskiego Trybunału Praw Człowieka. Dzięki wspomnianemu rozporządzeniu powstał stan prawny, który spowodował daleko idące zmiany w sposobie organizowania nie tylko lekcji etyki, lecz również religii. Szczegółowa analiza nowej sytuacji została przeprowadzona pod koniec 2014 roku na zlecenie Rzecznika Praw Obywatelskich. Z jego inicjatywy przeprowadzono badanie ankietowe, którego wyniki zostały opublikowane w raporcie pt. Dostępność lekcji religii wyznań mniejszościowych $i$ lekcji etyki $w$ ramach systemu edukacji szkolnej (2015). Warto przywołać przynajmniej niektóre ustalenia zaprezentowane w tym raporcie.

Powołując się na dane uzyskane z Ministerstwa Edukacji Narodowej, w powyższym raporcie podano, że w roku szkolnym 2014/15 w Polsce istniało 24769 szkół publicznych różnego szczebla (szkoły podstawowe, gimnazja, szkoły ponadgimnazjalne: szkoły zawodowe i licea ogólnokształcące). Lekcje etyki prowadzono w 2802 placówkach, co stanowi 11,3 proc. ogółu szkół publicznych w naszym kraju. Dla porównania w roku szkolnym 2006/2007 liczba ta wynosiła zaledwie 285. Jak łatwo obliczyć, nastąpił prawie dziesięciokrotny wzrost instytucji oświatowych oferujących zajęcia z etyki. W roku szkolnym, w którym przeprowadzono badanie ankietowe, lekcje etyki odbywały się w 24,4 proc. publicznych liceów ogólnokształcących, 12,4 proc. publicznych gimnazjów, 9,1 proc. publicznych szkół podstawowych i w zaledwie 5,6 proc. ogólnej liczby szkół zawodowych. Dla porównania szkoły z nauczaniem religii stanowiły w porządku zstępującym 99 proc. szkół 
podstawowych, 98,7 proc. gimnazjów, 97,5 proc. liceów ogólnokształcących i 95,1 proc. szkół zawodowych (Dostępność lekcji religii..., 2015, s. 34).

Wzrost liczby szkół publicznych, w których na podstawie wydanego rozporządzenia wprowadzono naukę etyki, spowodował wyraźne zwiększenie się liczby etatów nauczycieli tego przedmiotu. W roku szkolnym 2014/2015 było ich 504 . Porównując tę liczbę z 23414 etatami nauczycieli religii, może wydawać się ona znikoma - zalewie 2,15 proc., jednak w stosunku do roku szkolnego 2006/2007, kiedy to było zarejestrowanych 88 etatów nauczycieli etyki, stanowi to wzrost prawie sześciokrotny (Dostępność lekcji religii..., 2015, s. 35).

Powołując się na wywiady przeprowadzone z dyrektorami szkół, w tym samym opracowaniu stwierdza się, że co prawda dostrzegają oni wzrost zapotrzebowania na lekcje etyki, jednak nie organizują ich z powodu braku nauczycieli z odpowiednim przygotowaniem przedmiotowym i pedagogicznym. Dyrektorzy podali równocześnie, że 4,5 proc. nauczycieli etyki uczy także religii (przede wszystkim wyznania rzymskokatolickiego), 70,2 proc. uzupełnia zajęciami z etyki swoje pensum dydaktyczne z przedmiotu innego niż religia, a 25 proc. to nauczyciele wyłącznie etyki (Dostępność lekcji religii..., 2015, s. 43).

Dopełnieniem stanu nauczania etyki i religii w polskich szkołach niech będzie informacja, że lekcje etyki są prowadzone na cztery różne sposoby: po pierwsze, jako „normalna” lekcja, tzn. w jednolitym zespole klasowym, po drugie, jako zajęcia międzyoddziałowe, tzn. między oddziałami znajdującymi się na tym samym poziomie nauczania, po trzecie, jako zajęcia międzyklasowe, czyli dla uczniów z różnych klas tej samej szkoły i w końcu po czwarte, jako zajęcia międzyszkolne. Tygodniowa liczba godzin lekcji religii to 2 , a etyki -1 .

\section{Historia badania ETiK w Polsce}

Myśl o przeprowadzeniu w Polsce badania dotyczącego kompetencji moralno-etycznych zrodziła się w związku z zatrudnieniem w 2008 roku Dietricha Bennera na stanowisku profesora na Wydziale Nauk Pedagogicznych Uniwersytetu Kardynała Stefana Wyszyńskiego (UKSW) w Warszawie. W tym właśnie okresie wprowadzano w naszym kraju nowe zasady finansowania rozwoju nauki za pomocą otwartych konkursów, które wówczas przeprowadzało Ministerstwo Nauki i Szkolnictwa Wyższego (MNiSW). Nowy profesor miał za sobą zakończony sukcesem pierwszy etap projektu $\mathrm{ETiK}^{3}$, którym kierował na Uniwersytecie Humboldtów

\footnotetext{
${ }^{3}$ Skrót ETiK powstał od niemieckiej nazwy projektu „Entwicklung eines Testinstrumentes zu einer didaktisch und bildungstheoretisch ausgewiesenen Erfassung moralischer Kompetenzen, bezogen auf den Ethik-Unterricht an öffentlichen Schulen”, co w języku polskim oznacza: „Rozwój narzędzia badawczego służącego ujmowaniu dydaktycznie uzasadnionych kompetencji moralnych w odniesieniu do lekcji etyki w szkołach publicznych".
} 
(HU) i który sfinansowała elitarna dla nauki niemieckiej instytucja - Deutsche Forschungsgemeinschaft (DFG).

D. Benner jako kierownik powołanej do istnienia katedry Podstaw Pedagogiki Ogólnej wyznaczył sobie za cel ugruntowanie pedagogiki ogólnej jako samodzielnego obszaru badań pedagogicznych. Za najbardziej odpowiednie wydało mu się przeszczepienie na grunt polski projektu prowadzonego przez siebie w Berlinie. W tym celu razem z Dariuszem Stępkowskim przygotował do MNiSW wniosek zatytułowany Sporządzenie narzędzi badań nad kompetencjami moralnymi uczniów gimnazjum, kształtowanymi na lekcjach etyki (KoMoLEG), który został złożony w dniu 17 czerwca 2009 roku (oznaczenie: N N106 011138). Całkowity koszt realizacji zaplanowanego badania opiewał na kwotę 265 tys. zł.

Po pierwszym etapie procedury konkursowej wniosek został odrzucony. W decyzji z dnia 11 stycznia 2010 roku zastępca dyrektora Departamentu Instrumentów Polityki Naukowej MNiSW stwierdza: „W wyniku oceny wniosek został sklasyfikowany na pozycji 68 listy rankingowej projektów badawczych Zespołu Specjalistycznego Nauk Humanistycznych i Społecznych. Komisja Badań na Rzecz Rozwoju Nauki Rady Nauki na posiedzeniu w dniu 2009-12-17 nie rekomendowała wniosku do finansowania. Rekomendację komisji Rady Nauki do finansowania uzyskały wnioski do pozycji 32 ww. listy rankingowej zespołu" (Decyzja nr o111/B/ Ho3/2009/38 z dnia 11.01.2010 roku).

Zwraca jednak uwagę, że dołączone do tej decyzji opinie recenzentów były skrajnie przeciwstawne. Jeden $\mathrm{z}$ nich przyznał projektowi na możliwych 10 pkt aż 9,5 pkt i zaliczył go do wyróżniających się, drugi natomiast dał zaledwie 1 pkt i określił go jako „nie do przyjęcia”. Większe znaczenie od liczby punktów mają oczywiście racje merytoryczne przedstawione przez ekspertów. Pierwszy ze specjalistów w swojej recenzji stwierdził m.in.: „Bardzo interesujący projekt badawczy, mający na celu opracowanie narzędzi badawczych do diagnozowania kompetencji moralnych uczniów szkół gimnazjalnych. [...] Dla prowadzenia [...] rzeczowej dyskusji w tej sprawie konieczne jest dostarczenie dowodów empirycznych na podstawie opracowanych narzędzi i przeprowadzonych badań” (Recenzja 1, s. 1). W przeciwieństwie do tego drugi ekspert aż siedem razy użył zwrotu: „Nie rozumiem”. W ten sposób dał on wyraz brakowi zrozumienia dla:1) konieczności wydatkowania ponad ćwierć mln zł na narzędzie służące badaniu zajęć z etyki, to jest przedmiotu występującego w polskim systemie oświatowym tylko śladowo; 2) korzyści, jakie miałyby wyniknąć z ewaluacji nauczania etyki; 3) proponowanego podejścia badawczego; 4) sposobu mierzenia kompetencji etycznej za pomocą zadań testowych; 5) funkcji skali Rascha w analizie danych empirycznych; 6) podziału procedury badawczej na trzy etapy realizacji i 7) przedmiotu współpracy między UKSW a HU (Recenzja 2, s. 2).

W konkluzji swojej recenzji drugi ekspert wyraził przypuszczenie, że pochodzący z Niemiec kierownik projektu chce zapewne powiększyć swoje apanaże przez realizację w Polsce projektu zbliżonego, a nawet identycznego z tym, którym kieruje w Berlinie (Recenzja 2, s. 2). Na to niesłuszne podejrzenie wnioskodawcy 
odpowiedzieli listem z dnia 25 lutego 2010 roku, skierowanym do wspomnianego powyżej zastępcy dyrektora jednego z departamentów MNiSW. Wyjaśnili w nim, że w złożonym przez nich wniosku nie przewidywano wynagrodzenia ani dla kierownika projektu, tzn. D. Bennera, ani dla D. Stępkowskiego. Poza tym w fazie przygotowawczej obaj wnioskodawcy opłacali z prywatnych środków honorarium osobie, która po ewentualnym uzyskaniu dofinasowania miała wejść w skład zespołu realizującego badanie (List $z$ dnia 25.02.2010 roku).

Zachęcony opinią pierwszego z zaprezentowanych powyżej ekspertów i po sukcesie berlińskiego projektu ETiK, który pod koniec 2011 roku uzyskał kolejny grant ze środków DFG na realizację drugiego etapu badania ETiK, D. Stępkowski podjął ponowną próbę pozyskania środków na przeprowadzenie podobnego badania w Polsce. W tym celu wiosną 2012 roku powołał on do istnienia mały zespół badawczy ${ }^{4}$ i po trwających ponad rok przygotowaniach złożył jesienią 2013 roku w Narodowym Centrum Nauki (NCN) w ramach konkursu „Harmonia 5” wniosek pt. Adaptacja pedagogiczno-dydaktycznego Testu Kompetencji Moralnych Piętnastolatków (TKMP) Dietricha Bennera (nr wniosku DEC-2013/10/M/ HS6/o0431). W ramach projektu przewidziana była ścisła współpraca z zespołem badawczym kierowanym przez Georga Ritzera, który zawiązał się w tym właśnie okresie na Uniwersytecie Wiedeńskim i w Kirchliche Pädagogische Hochschule w Wiedniu. Głównym przedmiotem kooperacji miało być dostosowanie berlińskiego TKMP do specyfiki każdego z krajów - Polski i Austrii. W warszawskim badaniu zamierzano prześledzić również pozaszkolne czynniki warunkujące efektywność nauczania w zakresie moralności. Stąd w repertuarze narzędzi badawczych znalazła się Krótka Skala Inteligencji Mieczysława Choynowskiego, Skala Wartości Schelerowskich Piotra Brzozowskiego i Kwestionariusz Środowiskowy autorstwa jednego z członków zespołu - Bartłomieja Skowrońskiego. Chcąc sprostać rygorom narzuconym procedurze adaptacji obcego narzędzia badawczego, w harmonogramie projektu przewidziano sprawdzenie jakości tłumaczenia zadań testowych $\mathrm{z}$ języka niemieckiego na polski przez badanie pilotażowe $\mathrm{w}$ dwóch szkołach polskich w Wiedniu, a mianowicie: Pierwszej Społecznej Szkole Polskiej w Austrii i Szkolnym Punkcie Konsultacyjnym im. Jana III Sobieskiego przy Ambasadzie RP.

Podczas gdy badanie wiedeńskie uzyskało dofinansowanie $\mathrm{z}$ austriackiego Bundesministerium für Wissenschaft, Forschung und Wirtschaft (Ministerstwo Nauki, Badań i Gospodarki), rozpatrywany w tym samym czasie w NCN warszawski wniosek został oceniony negatywnie (Decyzja dyrektora Narodowego Centrum Nauki z dnia 23.01.2014 roku, s. 1). Należy podkreślić, że zarówno wiedeński, jak

4 W latach 2012-2015 skład zespołu ulegał ciągłym zmianom. W różnych okresach współpracowały w nim następujące osoby: dr Wanda Kamińska, mgr Anna Ksionek, mgr Anna PerczyńskaAbramowicz, mgr Joanna Pękala, lic. Tomasz Piast-Szlubowski, dr Bartłomiej Skowroński i dr Sabina L. Zalewska. 
i warszawski zespół ETiK miały być wspierane w obliczeniach statystycznych i analizach komparatystycznych przez członków teamu z Berlina. Tymczasem recenzenci polskiego wniosku uznali za niewystarczające jakość narzędzia badawczego i przygotowanie kierownika zespołu do prowadzenia badania empirycznego. Mimo to jeden $z$ nich stwierdził w swojej opinii: „Myśl, by móc rzetelnie mierzyć kompetencje moralne, jest kusząca, choć podobne narzędzia (np. Kohlberga czy Resta) dały więcej dymu niż ognia - być może dlatego, że moralność należy raczej do porządku działania niż myślenia. Ale próbować warto. Rzecz w tym, by od razu wprząc pomiar w teoretycznie uzasadniony pomysł badawczy" (Uzasadnienie do decyzji dyrektora Narodowego Centrum Nauki z dnia 23.01.2014 roku, s. 5).

Odrzucenie wniosku na przeprowadzenie badania ETiK w Polsce zmusiło D. Stępkowskiego do zaniechania dalszych prób ubiegania się o środki ogólnopolskie i do dostosowania zamierzania badawczego do możliwości macierzystej jednostki naukowej - WNP UKSW. W tym celu przygotował on wniosek o grant w ramach badań statutowych na rok 2014 pt. Zadania, możliwości i granice ksztattowania kompetencji moralnych na lekcjach etyki w gimnazjum, który uzyskał akceptację wydziałowej Komisji ds. Badań Naukowych. Dzięki temu zespół uzyskał skromną kwotę w wysokości pięciu tys. zł na przygotowanie i przeprowadzenie badania terenowego (umowa nr UmoPBNP-9/14).

Względy finansowe zadecydowały o tym, że w wydziałowym projekcie zrezygnowano z próby obejmującej całą Polskę i postanowiono ograniczyć badanie do terenu Warszawy i województwa mazowieckiego. Aby maksymalnie ograniczyć wydatki, zrezygnowano również z testu pilotażowego, a zestaw zadań testowych ograniczono do pytań, które po badaniu pilotażowym zespołu wiedeńskiego zostały wyselekcjonowane jako odpowiednie dla kontekstu kulturowego w Austrii.

\section{Badanie ETiK-International w Warszawie}

Poniższe rozważania podzielono na dwie części. W pierwszej zostaną omówione przygotowania do badania ETiK-International Warszawa i jego przebieg. Druga część zawiera charakterystykę badanej populacji i analizę uzyskanych wyników.

\section{Przygotowania i przebieg badania terenowego}

Prace nad przekładem zadań testowych tworzących trzon TKM-EP rozpoczęły się bezpośrednio po złożeniu wniosku do NCN, to jest w październiku 2013 roku. Po powzięciu wiadomości o odrzuceniu wniosku zmodyfikowano pulę zadań testowych. $Z$ jednej strony ograniczono liczbę pytań dotyczących etyki, z drugiej natomiast rozszerzono zakres tematyczny o zadania odnoszące się do kompetencji religijnej. Jak wspomniano powyżej, zadania te wyselekcjonowali członkowie wiedeńskiego zespołu z zestawu pytań opracowanych w innym berlińskim projekcie, 
a mianowicie KERK ${ }^{5}$ i dołączyli do swojego badania. Przez przejęcie wiedeńskiego zestawu chciano w Warszawie zabezpieczyć możliwość porównania wyników uzyskanych w obu projektach. Prace przygotowawcze zakończono w marcu 2014 roku. W ich wyniku powstały dwa zeszyty różniące się między sobą tylko kolejnością zadań. Każda wersja składała się z pięciu części: 1) wprowadzenie, w którym uczestnikom badania wyjaśniono cel badania i sposób pracy nad zadaniami; 2) testu figur; 3) 49 zadań dotyczących kompetencji moralno-etycznych; 4) 36 zadań odnoszących się do kompetencji religijnej i 5) 11 pytań metryczki. Czas konieczny na rozwiązanie całego pakietu oszacowano na $90 \mathrm{~min}$, to jest dwie godz. lekcyjne bez przerwy. Do przeprowadzenia badania terenowego pozyskano 11 ankieterów. Byli nimi studenci i studentki WNP UKSW, którzy zostali odpowiednio przeszkoleni.

Doboru szkół dokonano za pomocą losowania spośród gimnazjów znajdujących się na dostępnej w internecie ogólnopolskiej liście szkół, w których w roku szkolnym 2013/2014 uczono etyki (Etyka w szkole, 30.09.2013). Lista ta obejmowała w sumie 1326 placówek oświatowych, z czego w województwie mazowieckim (włącznie z Warszawą) znajdowało się 347 (26,1 proc.). Z tej puli celem przeprowadzenia badania $z$ terenu Warszawy zostało wylosowanych 20 gimnazjów i tyle samo z województwa mazowieckiego.

W kwietniu 2014 roku nawiązano kontakt z wybranymi losowo gimnazjami. Ten okres okazał się jednak szczególnie niekorzystny do prowadzenia badania, gdyż właśnie kończyły się ostatnie przygotowania do ogólnopolskiego egzaminu gimnazjalnego, który tego roku był zaplanowany na 23-25 kwietnia. Z tego powodu część dyrektorów od razu odrzucała propozycję wzięcia udział w badaniu ETiK, wskazując na przeciążenie uczniów i niedobór czasu na realizację programu nauczania. Znacznie poważniejszą przyczyną braku zgody było jednak to, że wielu z nich przyznawało, że w kierowanych przez nich placówkach lekcje etyki de facto się nie odbywają. Zdarzyło się również i tak, że mimo uzyskania zgody dyrektora nauczycielka etyki odmówiła współpracy po zapoznaniu się z zawartością zeszytów testowych. Swoją decyzję uzasadniała tym, że pytania w nich zawarte są zbyt złożone, a część z nich dotyczy zagadnień religijnych, które jej zdaniem nie mają nic wspólnego $z$ etyką.

Do przeprowadzenia badania pozyskano pięć gimnazjów z terenu Warszawy (trzy publiczne i dwa niepubliczne) i sześć z województwa mazowieckiego (wszystkie publiczne). To dawało łączną liczbę 323 uczestników. Zgodnie z informacjami, uzyskanymi od dyrektorów placówek, 255 uczniów miało uczęszczać na katolickie lekcje religii i tylko 68 na lekcje etyki. Ten niezadowalający stan pogorszył się jeszcze bardziej po przestudiowaniu metryczek zawartych w zeszytach testowych. Okazało

\footnotetext{
5 Akronim powstał z pełnej nazwy projektu: „Konstruktion und Erhebung von Religiösen Kompetenzniveaus im Religionsunterricht am Beispiel des Evangelischen Religionsunterrichts”, co oznacza: „Konstrukcja i sprawdzenie poziomów kompetencji religijnej w odniesieniu do szkolnego nauczania religii na przykładzie ewangelickich lekcji religii”. Zob. Willems i in. 2014.
} 
się wówczas, że we wskazanych gimnazjach tylko 23 uczniów zaznaczyło, że bierze udział w lekcjach etyki, natomiast ośmiu innych podało, że uczęszczają zarówno na lekcje religii, jak i etyki. Tak więc w badanej populacji kontakt $\mathrm{z}$ etyką jako przedmiotem szkolnym miało zaledwie 31 osób. Aby przynajmniej zagwarantować możliwość porównania wyników uzyskanych w Polsce z tymi, które zgromadził zespół wiedeński, pozyskano do badania jeszcze cztery gimnazja prowadzone przez katolickie organy prowadzące (wszystkie to gimnazja niepubliczne). Co prawda w gimnazjach tych lekcje etyki się nie odbywały, jednak dyrektorzy wyrażali zainteresowanie tym, jakie wyniki osiągną ich uczniowie w teście kompetencji moralno-etycznych. Tak więc łączna liczba placówek oświatowych biorących udział w warszawskim badaniu ETiK wyniosła 15, natomiast liczba uczniów - nieco ponad 500.

Badanie terenowe odbywało się od 15 maja do 30 czerwca 2014 roku i zostało przeprowadzone przez 11 ankieterów w ośmiu gimnazjach warszawskich ( 53 proc.) i siedmiu województwa mazowieckiego (47 proc.). Należy zauważyć, że szkoły spoza Warszawy znajdowały się w bezpośredniej bliskości stolicy, a mianowicie w takich podwarszawskich miejscowościach, jak Józefosław, Dziekanów Leśny czy Pruszków. Szkół publicznych było dziewięć (6o proc.), natomiast niepublicznych sześć (40 proc.), z tego cztery szkoły katolickie i dwie prowadzone przez inne niepaństwowe organy prowadzące. Spośród uczestniczących w badaniu 511 uczniów 167 (32,68 proc.) uczęszczało do gimnazjów katolickich. Wszyscy byli uczniami trzeciej i ostatniej klasy tego typu szkoły.

\section{Modyfikacja problemu badawczego, charakterystyka populacji i analiza wyników}

W warszawskim badaniu ETiK wskutek zaprezentowanych powyżej trudności niemożliwa była realizacja pierwotnego celu. Zbyt mały udział procentowy uczniów uczestniczących w lekcjach etyki i nieproporcjonalnie większa grupa uczniów uczęszczających tylko na zajęcia z religii spowodowały również konieczność zmodyfikowania głównego problemu badawczego. W tej sytuacji jedynie możliwe stało się określenie poziomu kompetencji moralno-etycznych polskich piętnastolatków niezależnie od faktu uczęszczania lub nieuczęszczania na lekcje etyki w gimnazjum.

Uczestnictwo w badaniu było dobrowolne. W odniesieniu do uczniów i uczennic, którzy wzięli w nim udział, można stwierdzić, że była to grupa mocno zróżnicowana pod względem społecznym, etnicznym i kognitywnym. Czynniki potwierdzające to zróżnicowanie zostały ujęte i dokładnie przeanalizowane. W wyniku tej analizy okazało się, że wywierają one znaczący wpływ na uzyskiwane w szkole przez gimnazjalistów kompetencje zarówno moralno-etyczne, jak i religijne. Do czynników tych należy w szczególności kontekst społeczno-kulturowy, który poddano mierzeniu za pomocą określenia zasobu biblioteczki domowej (do 100 książek versus więcej niż 100 książek). Wskaźnikiem, z pomocą którego starano się opisać 
kontekst etniczny, było pytanie o język, którym mówi się w rodzinie najczęściej (język polski versus inne języki). Czynniki kognitywne warunkujące nabywanie przez nastolatków kompetencji moralno-etycznych i religijnych poddano oszacowaniu za pomocą niewerbalnego testu inteligencji - Kognitives Fähigkeitstest (KFT; Heller, Perleth 200o).

Dane przedstawione w poniższej tabeli wskazują na znaczące różnice między 15 gimnazjami, których uczniowie wzięli udział w badaniu (gimnazja te oznaczono kolejno wielkimi literami alfabetu, od A do O). Udział uczniów pochodzących z rodzin, w których biblioteczka domowa zawiera mniej niż 100 woluminów, osiąga w szkole A aż 74 proc., natomiast w szkole oznaczonej literą O wynosi zaledwie 7 proc.. Równie nieproporcjonalne różnice można zaobserwować w odniesieniu do płci. Jeżeli pominie się gimnazjum M, które jest szkołą wyłącznie dla dziewcząt, i gimnazjum D, przeznaczone wyłącznie dla chłopców, to wśród badanych udział respondentów płci żeńskiej waha się od 46 proc. w gimnazjum C do 78 proc. w gimnazjum oznaczonym literą I.

Wskazanym powyżej różnicom co do kontekstu społeczno-kulturowego towarzyszą również istotne statystycznie dysproporcje między uczniami 15 gimnazjów Warszawy i województwa mazowieckiego w obszarze kognitywnych uwarunkowań uczenia się, innymi słowy: poziomu inteligencji. Średni wynik KFT w gimnazjum A wyniósł 12,1 pkt $(s=1,8)$ i był znacząco niższy od wyniku uzyskanego przez uczniów gimnazjum $\mathrm{O}$, w którym średnia wyników uzyskanych za pomocą testu figur wyniosła 21,1 pkt.

Aby przy analizie zgromadzonych danych należycie uwzględnić wskazane powyżej dysproporcje, 15 uczestniczących w badaniu gimnazjów podzielono na trzy grupy zbliżone co do właściwości psychometrycznych uczniów, którzy do nich uczęszczają. Przy tworzeniu tych grup uwzględniono w szczególności poziom możliwości kognitywnych i kontekst społeczno-kulturowy.

Pierwsza z grup (G I) obejmowała pięć gimnazjów, w których odnośnie do poziomu inteligencji średnia wartość uzyskana przez respondentów w KFT wyniosła 14,7 pkt, natomiast 46,8 proc. uczniów pochodziła z rodzin posiadających w swojej biblioteczce domowej mniej niż 100 książek. Gimnazja te w zakresie warunków społeczno-kulturowych i kognitywnych przejawiały najmniej korzystne parametry. Jeżeli chodzi o podział ze względu na płeć, była w nich zachowana równowaga między chłopcami i dziewczętami, z lekką jednak przewagą tych ostatnich. Badani uczniowie podawali, że przeciętnie 28,5 proc. $z$ nich często lub wyłącznie używa w domu innego języka niż polski. W odniesieniu do pozostałych dwóch grup ten wynik był najniższy. 
Tabela 1. Podział gimnazjów na trzy grupy ze względu na cechy populacji

\begin{tabular}{|c|c|c|c|c|c|c|c|}
\hline Gimnazjum & $\begin{array}{l}\text { Test } \\
\text { KFT }\end{array}$ & \begin{tabular}{|c|} 
Płeć \\
$(\dot{\mathrm{z}})$ \\
$(\mathrm{w}$ proc. $)$ \\
\end{tabular} & $\begin{array}{c}\text { Język } \\
\text { (niepolski) }\end{array}$ & $\begin{array}{c}\text { Książki } \\
(<\mathbf{1 0 0})\end{array}$ & \multicolumn{2}{|l|}{ Grupa } & $\mathbf{N}$ \\
\hline A & 12,1 & \begin{tabular}{|l|}
57 \\
\end{tabular} & 18 & 74 & \multirow{5}{*}{$\begin{array}{l}\text { a) zdolności kog- } \\
\text { nitywne, poniżej } \\
\text { przeciętnych; } \\
\text { b) ponadprze- } \\
\text { ciętny udział } \\
\text { uczniów z ma- } \\
\text { lym księgozbio- } \\
\text { rem domowym }\end{array}$} & \multirow{5}{*}{$\begin{array}{l}{ }^{*} \mathrm{KFT}=14,7 \\
\star \text { do } 100 \text { ksią- } \\
\text { zek }=46,8 \\
\text { proc. } \\
{ }^{\star} \text { dziewczęta }= \\
52,3 \text { proc. } \\
{ }^{*} \text { niepol- } \\
\text { ski=28,5 proc. }\end{array}$} & 47 \\
\hline B & 14,7 & 68 & 41 & 45 & & & 37 \\
\hline $\mathrm{C}$ & 16 & 46 & 31 & 27 & & & 44 \\
\hline $\mathrm{D}$ & 16,4 & $\mathrm{O}$ & 23 & 15 & & & 13 \\
\hline $\mathbf{E}$ & 16,4 & 62 & 32 & 45 & & & 22 \\
\hline $\mathbf{F}$ & 16,6 & 56 & 41 & 38 & \multirow{5}{*}{$\begin{array}{l}\text { a) przeciętne } \\
\text { zdolności } \\
\text { kognitywne; } \\
\text { b) przeciętny } \\
\text { udział ucz- } \\
\text { niów z małym } \\
\text { księgozbiorem } \\
\text { domowym } \\
\end{array}$} & \multirow{5}{*}{$\begin{array}{l}{ }^{*} \mathrm{KFT}=17,7 \\
{ }^{\star} \text { do } 100 \\
\text { książek }=30,2 \\
\text { proc. } \\
{ }^{\star} \text { dziewczęta }= \\
\text { 6o,5 proc. } \\
{ }^{\star} \text { niepolski }= \\
\text { 41,6 proc. }\end{array}$} & 40 \\
\hline $\mathrm{G}$ & 17,3 & 55 & 71 & 24 & & & 22 \\
\hline $\mathbf{H}$ & 17,5 & 47 & 47 & 30 & & & 21 \\
\hline I & 17,7 & 78 & 27 & 38 & & & 50 \\
\hline $\mathbf{J}$ & 18,4 & 56 & 42 & 23 & & & 76 \\
\hline K & 18,6 & 53 & 41 & 39 & \multirow{5}{*}{$\begin{array}{l}\text { a) ponadprze- } \\
\text { ciętne zdolności } \\
\text { kognitywne; } \\
\text { b) udział ucz- } \\
\text { niów z małym } \\
\text { księgozbio- } \\
\text { rem domo- } \\
\text { wym, poniżej } \\
\text { przeciętnego } \\
\end{array}$} & \multirow{5}{*}{$\begin{array}{l}{ }^{*} \mathrm{KFT}=19,2 \\
{ }^{*} \text { do } 100 \text { ksią- } \\
\text { żek }=25 \text { proc. } \\
{ }^{*} \text { dziewczęta }= \\
61,8 \text { proc. } \\
{ }^{*} \text { niepolski }= \\
\text { 39,1 proc. }\end{array}$} & 61 \\
\hline $\mathrm{L}$ & 19,1 & 48 & 25 & 17 & & & 29 \\
\hline $\mathbf{M}$ & 19,5 & 100 & 43 & 11 & & & 28 \\
\hline $\mathbf{N}$ & 19,7 & 67 & 67 & 23 & & & 6 \\
\hline \multirow[t]{2}{*}{$\mathbf{O}$} & 21,1 & 47 & 40 & 7 & & & 15 \\
\hline & $17,1 \%$ & $58 \%$ & $37 \%$ & $33 \%$ & & & 511 \\
\hline
\end{tabular}

Źródło: opracowanie własne (Stanislav Ivanov).

W drugiej grupie (G II) znalazło się pięć gimnazjów, których uczniowie w teście inteligencji KFT osiągnęli średni wynik 17,7 pkt przy o połowę wyższym odchyleniu standardowym niż w przypadku grupy pierwszej. W grupie tej widoczne jest wyraźne zmniejszenie o 16,6 pkt proc. udziału uczniów wywodzących się ze słabszych środowisk społeczno-kulturowych. Dziewczęta są w niej nadreprezentowane $(60,5$ proc.). Uczniów, którzy zaznaczyli inny język niż polski jako dominujący w ich rodzinach, jest o około 13 proc. więcej niż w grupie pierwszej.

Najkorzystniej pod względem właściwości psychometrycznych badanej populacji przedstawia się trzecia grupa gimnazjów (G III). Tak jak poprzednio tworzy ją pięć placówek oświatowych. Dwie trzecie uczęszczających do nich nastolatków 
pochodzi z rodzin o ponadprzeciętnie wysokim statusie społeczno-kulturowym. Średnia wartość uzyskana przez tych uczniów w figuratywnym teście KFT wynosi 19,2 pkt i po uwzględnieniu $s=0,30$ przewyższa o jedną trzecią odchylenia standardowego wartości punktowe osiągnięte w grupie drugiej i o prawie całe odchylenie standardowe $(s=0,90)$ osiągnięcia gimnazjalistów z pierwszej grupy. Udział uczniów deklarujących posługiwanie się w domu rodzinnym językiem inny niż polski wynosi 39,1 proc., co oznacza poziom porównywalny z drugą grupą.

Na znajdującym się poniżej wykresie przedstawiono różnice średnich wartości uzyskanych przez uczniów trzech grup gimnazjów w odniesieniu do kompetencji moralno-etycznych, w której zgodnie z koncepcją teoretyczną wyróżniono: 1) podstawową wiedzę moralno-etyczną (PWM-E); 2) kompetencję sądzenia moralno-etycznego (KSM-E) i 3) kompetencję projektowania działania moralno-etycznego (KPDM-E), przy czym średnie wyników uzyskanych przez uczniów drugiej grupy gimnazjów stanowią wartość referencyjną zero.

Wykres 1. Różnice średnich wartości uzyskanych w zakresie podstawowej wiedzy moralno-etycznej (PWM-E), kompetencji sądzenia moralno-etycznego (KSM-E) i kompetencji projektowania działania moralno-etycznego (KPDM-E) na zakończenie trzeciego etapu kształcenia (wartość referencyjna: wyniki G II)

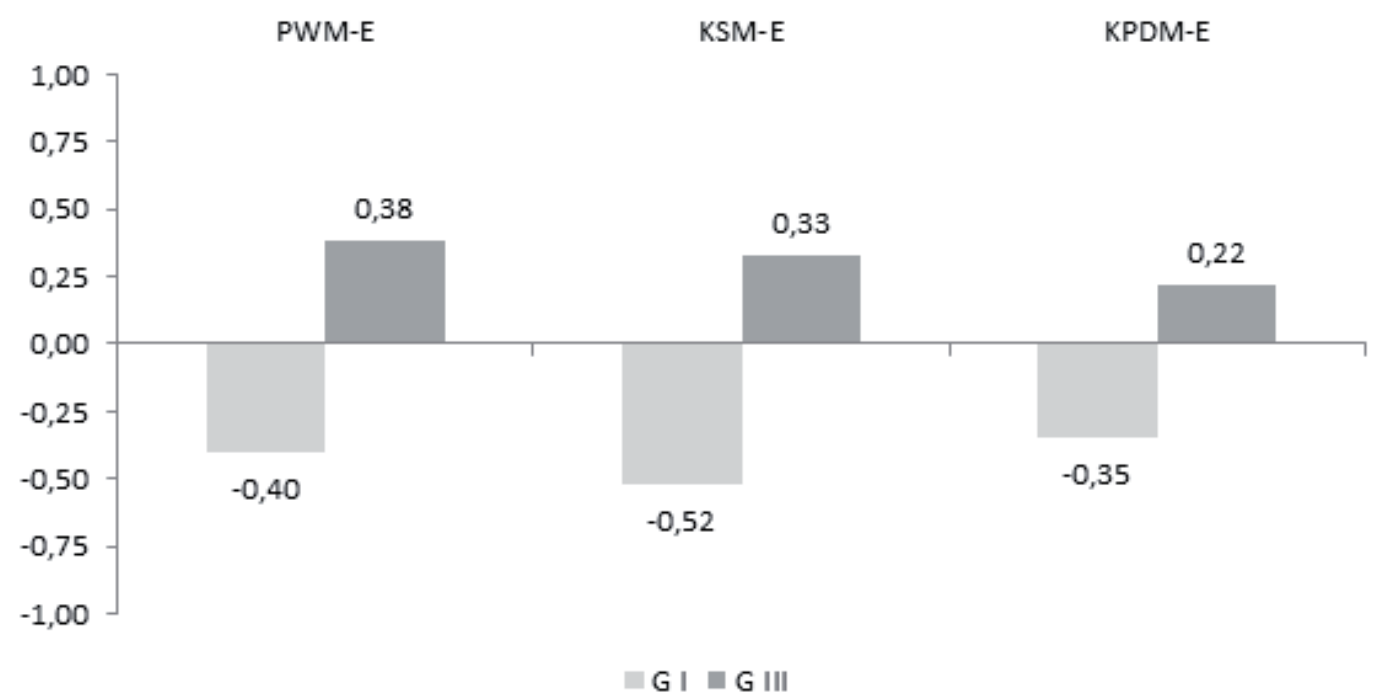

Źródło: opracowanie własne (Stanislav Ivanov).

Zobrazowane powyżej wyniki wskazują, że gimnazjaliści należący do pierwszej grupy we wszystkich trzech zakresach kompetencji moralno-etycznych, a mianowicie: podstawowej wiedzy moralno-etycznej $(-0,40)$, kompetencji sądzenia moralno-etycznego $(-0,52)$ i kompetencji projektowania działania moralno-etycznego $(-0,35)$ wyraźnie odstają od swoich rówieśników z drugiej grupy gimnazjów. Ci ostatni natomiast osiągając w tych samych zakresach wartości odpowiednio: -o,38 
(PWM-E), -o,33 (KSM-E) i -o,22 (KPDM-E), sytuują się znacznie poniżej wyników uczniów z pierwszej grupy gimnazjów.

Podobna sytuacja panuje również w odniesieniu do osiągniętego poziomu rozwoju w ramach wymienionych powyżej trzech zakresów kompetencji moralno-etycznych. Poziomy te zostały ustalone na podstawie oczekiwań dotyczących danego zakresu kompetencji moralno-etycznych i tworzą trzy odrębne skale (Stępkowski 2015b, s. 224-228). Po odniesieniu wyników uzyskanych przez uczniów w omawianych grupach gimnazjów do tychże skal okazało się, że zachodzą między nimi znaczne różnice. Zobrazowaniem tego jest kolejny wykres.

Wykres 2. Rozkład wyników uzyskanych przez gimnazjalistów w odniesieniu do skali podstawowej wiedzy moralno-etycznej (PWM-E), skali kompetencji sądzenia moralno-etycznych (KSM-E) i skali kompetencji projektowania działania moralno-etycznego (KPDM-E) na zakończenie trzeciego etapu kształcenia (wartości podano w proc.)

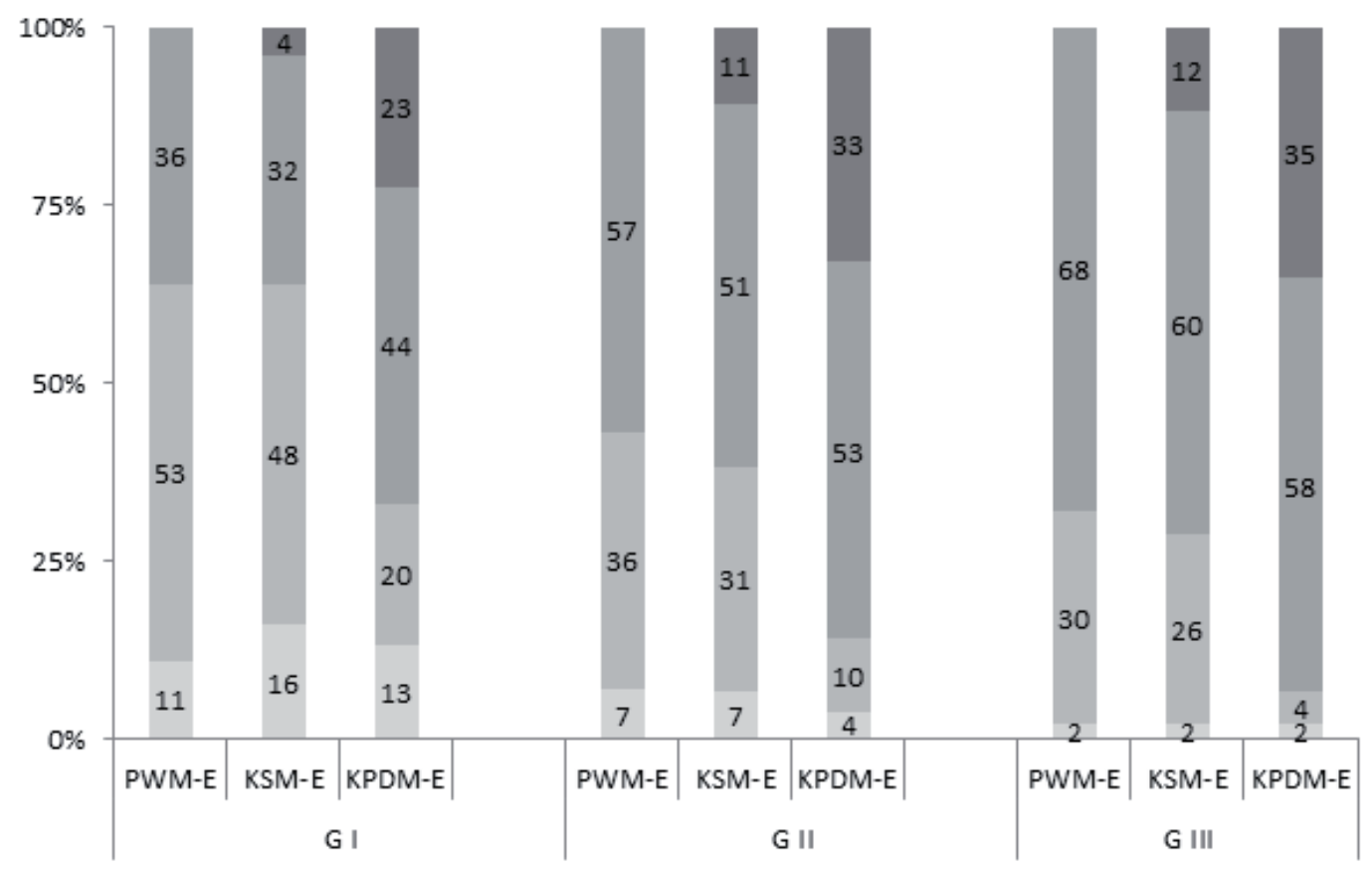

Źródło: opracowanie własne (Stanislav Ivanov).

Jeżeli pod koniec trzeciego etapu kształcenia ogólnego przyjąć za regułę, że kończący go absolwenci gimnazjum powinni we wszystkich zakresach kompetencji moralno-etycznych osiągnąć trzeci poziom, to wówczas okaże się, że w pierwszej grupie dwie trzecie gimnazjalistów znalazło się na skali PWM-E i skali KSM-E poniżej tego oczekiwania, a jedna trzecia na skali KPDM-E. Co prawda, wyniki uzyskane przez uczęszczających do gimnazjów z drugiej grupy wypadają nieco lepiej niż ich rówieśników z pierwszej grupy, gdyż osiągnęli oni następujące wartości procentowe: 43, 38 i 14 dla następujących skal: PWM-E, KSM-E i KPDM-E, 
niemniej jednak te wartości wciąż są substancjalnie słabe. Jedynie w trzeciej grupie zanotowano rezultaty mogące uchodzić za zadowalające, gdyż przeważająca część gimnazjalistów w każdej z trzech skal kompetencji moralno-etycznych sprostała stawianemu przed nimi oczekiwaniu osiągnięcia trzeciego poziomu.

Odnośnie do osiągnięć dziewcząt i chłopców pod koniec trzeciego etapu kształcenia da się zauważyć, że w zależności od grupy osiągnięcia te silnie się różnicują. Wyniki analizy tego problemu przedstawia następny wykres.

Wykres 3. Średnie wartości punktów uzyskanych przez dziewczęta w zakresie podstawowej wiedzy moralno-etycznej (PWM-E), kompetencji sądzenia moralno-etycznego (KSM-E) i kompetencji projektowania działania moralno-etycznego (KPDM-E) na zakończenie trzeciego etapu kształcenia (grupa referencyjna: chłopcy)
G I
G II
G III

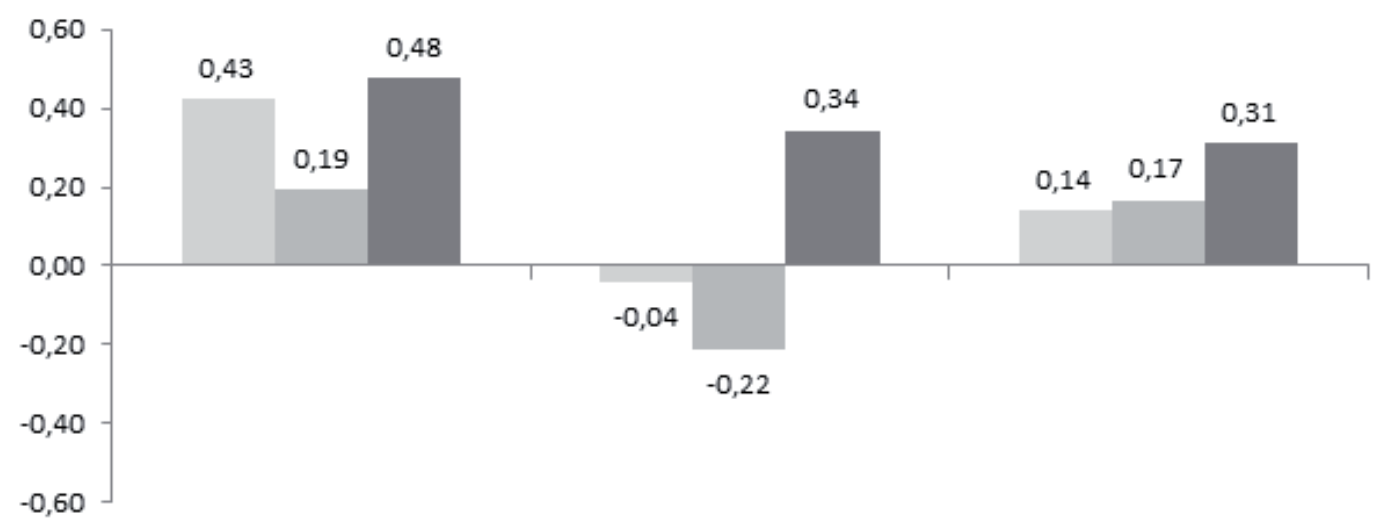

PWM-E $\square$ KSM-E $\square$ KPDM-E

Źródło: opracowanie własne (Stanislav Ivanov).

Jak wyraźnie widać z powyższego wykresu, w pierwszej grupie dziewczęta okazały się we wszystkich zakresach kompetencji moralno-etycznych lepsze niż ich koledzy. Wyniki dziewcząt na skali KSM-E przy różnicy wartości średniej wynoszącej o,19 były znacząco wyższe niż chłopców. Te osiągnięcia nabierają jeszcze bardziej substancjalnego charakteru w odniesieniu do skali PWM-E i skali KPDM-E, w których różnica średnich wyniosła odpowiednio o,43 i o,48.

Wyższe wskaźniki kompetencji moralno-etycznych zanotowano również w trzeciej grupie gimnazjów, gdzie jednak różnice w wartościach średnich osiągniętych przez chłopców i dziewczęta były mniej spektakularne niż w grupie pierwszej. Interesująca może być analiza efektu płciowego w drugiej grupie. Podczas gdy na skali KPDM-E dziewczęta wyraźnie górują, ich wyniki w obu pozostałych zakresach, tzn. PWM-E i KSM-E, są gorsze niż chłopców, a w przypadku tej ostatniej skali można powiedzieć, że znacząco ustępują swoim męskim rówieśnikom. 
W drugiej grupie gimnazjalistki i gimnazjaliści, którzy zaznaczyli w metryczce, że w domu posługują się przeważnie innym językiem niż polski, charakteryzują się w stosunku do swoich koleżanek i kolegów z rodzin mówiących po polsku wyraźnymi niedoborami we wszystkich skalach kompetencji moralno-etycznych, a mianowicie w skali PWM-E (-0,22), skali KSM-E $(-0,18)$ i skali KPDM-E $(-0,27)$. W trzeciej grupie gimnazjów uczniowie używający w domu najczęściej lub wyłącznie języka polskiego nie wykazują, oprócz skali KPDM-E, większych różnic co do poziomu rozwoju kompetencji moralno-etycznych w porównaniu ze swoimi kolegami mówiącymi w domu innymi językami. Zaskakujące są natomiast dane uzyskane w pierwszej grupie. Tutaj we wszystkich skalach wartości średnie osiągnięte przez gimnazjalistów mówiących w domu po polsku znacząco przewyższają uśrednione wyniki tych, którzy używają w rodzinie innego języka niż polski. Te wartości są następujące: 0,32 dla skali PWM-E, o,3o dla skali KSM-E i o,46 dla skali KPDM-E. Przedstawione zależności prezentuje graficznie poniższy wykres.

Wykres 4. Różnice wartości średnich uzyskanych w zakresie podstawowej wiedzy moralno-etycznej (PWM-E), kompetencji sądzenia moralno-etycznego (KSM-E) i kompetencji projektowania działania moralno-etycznego (KPDM-E) na zakończenie trzeciego etapu kształcenia w zależności od języka używanego w domu i przynależności do grupy (grupa referencyjna: język polski jako język najczęściej używany w domu)

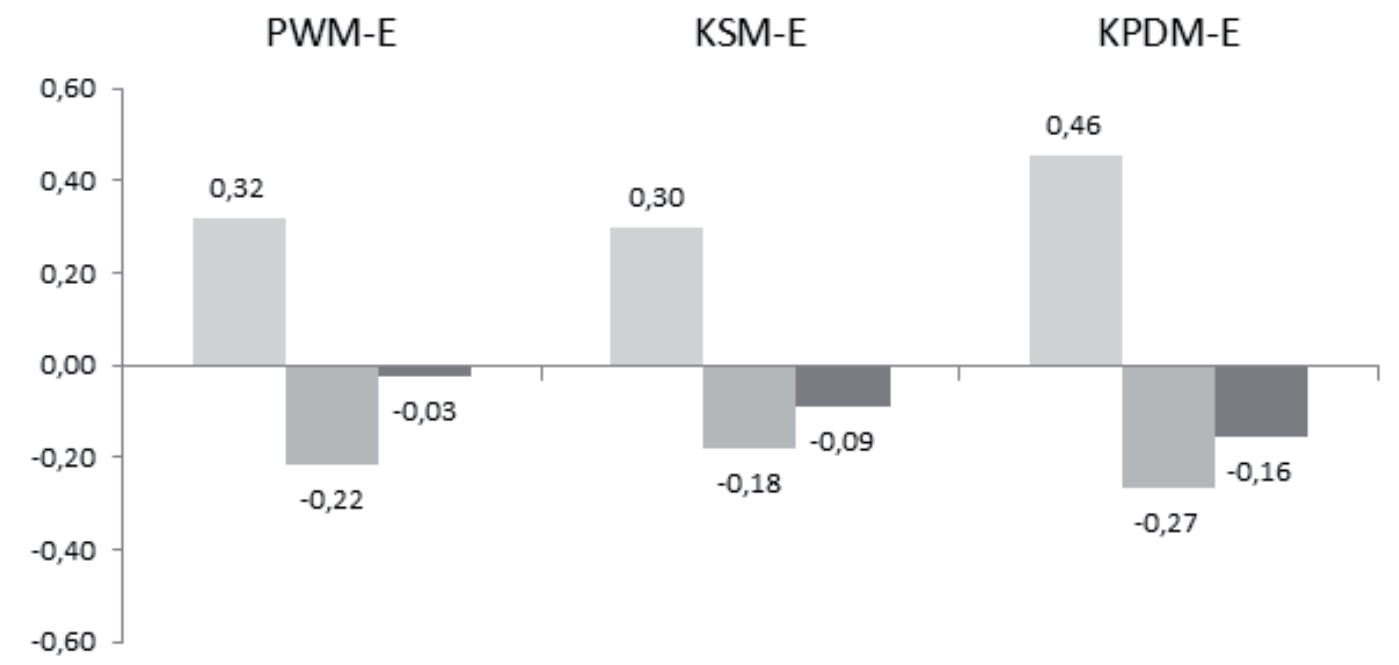

$\square \mathrm{GI} \square \mathrm{G}$ II $\square \mathrm{G}$ III

Źródło: opracowanie własne (Stanislav Ivanov).

Jak wspomniano już powyżej, w warszawskim badaniu wzięło udział zaledwie 31 uczniów i uczennic, którzy uczestniczyli w lekcjach etyki prowadzonych w gimnazjum. W grupie pierwszej było to łącznie 12 osób, co na tle pozostałych dwóch grup stanowi proporcjonalnie największy udział. Z tego powodu w dalszej analizie 
ograniczymy się wyłącznie do danych uzyskanych w tej grupie. Przede wszystkich będzie nas interesowało znalezienie odpowiedzi na pytanie, jaki poziom kompetencji moralno-etycznych w poszczególnych jej zakresach osiągnęli uczniowie uczestniczący w lekcjach etyki w gimnazjum i ci, którzy w nich nie brali udziału.

Na kolejnym wykresie zestawiono obie te grupy gimnazjalistów - tych, którzy uczęszczali na zajęcia $\mathrm{z}$ etyki i tych, którzy nie uczęszczali na te lekcje - w odniesieniu do osiągniętego przez nich poziomu kompetencji moralno-etycznych, określonych za pomocą skali PWM-E, skali KSM-E i skali KPDM-E.

Wykres 5. Zestawienie uczniów gimnazjum należących do pierwszej grupy ze względu na uczęszczanie i nieuczęszczanie na lekcje etyki w odniesieniu do skali podstawowej wiedzy moralno-etycznej (PWM-E), skali kompetencji sądzenia moralno-etycznego (KSM-E) i skali kompetencji projektowania działania moralno-etycznego (KPDM-E)

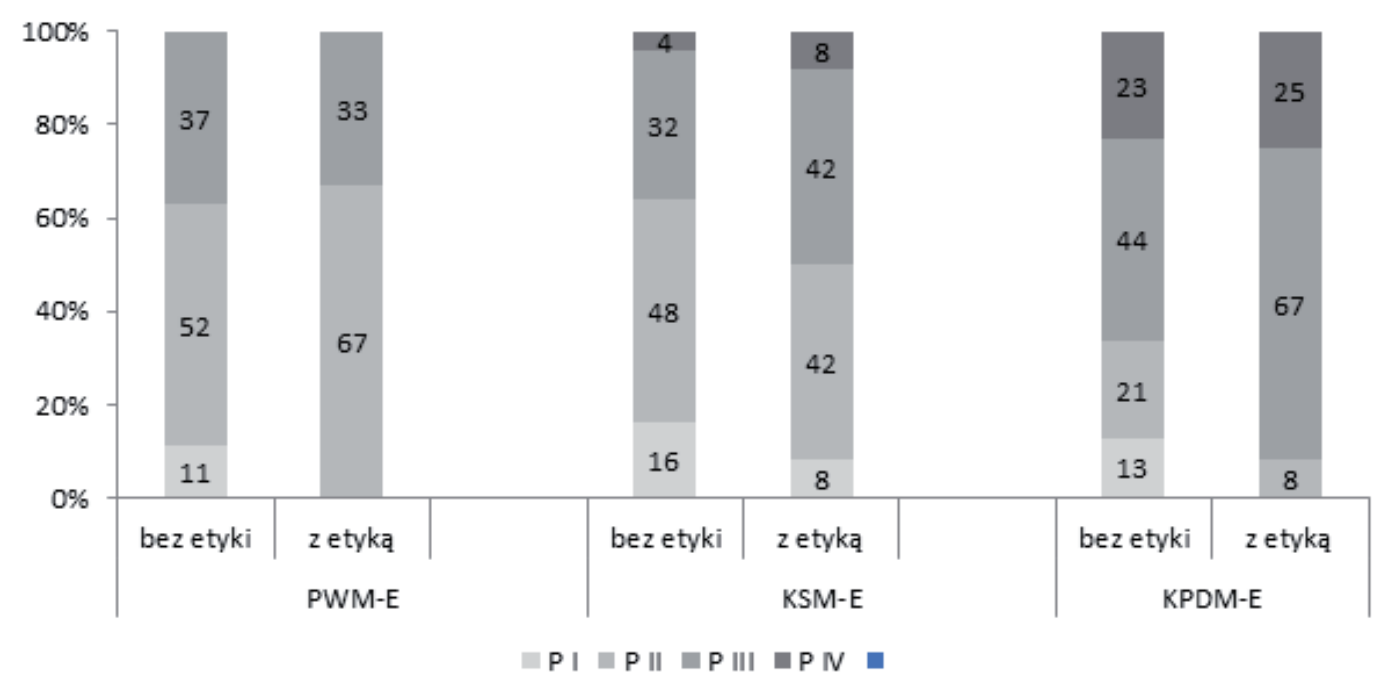

Źródło: opracowanie własne (Stanislav Ivanov).

Na powyższym wykresie zwraca uwagę to, że żaden z uczniów uczęszczających na lekcje etyki w gimnazjum nie znalazł się na najniższym poziomie w którejkolwiek z trzech skal kompetencji moralno-etycznych. Wręcz przeciwnie, uczniowie nieuczęszczający na zajęcia $\mathrm{z}$ etyki sytuują się na najniższych poziomach kompetencyjnych w zależności od rodzaju skali między 11 a 16 proc. Poza tym na skalach KSM-E i KPDM-E widoczne jest wyraźne przesunięcie ku górze w odniesieniu do poziomów osiąganych przez uczniów uczestniczących w lekcjach etyki. W obu tych skalach dwa najwyższe poziomy są osiągane przez odpowiednio 50 proc. i 92 proc. wspomnianych uczniów. Uczniom nieuczęszczającym na etykę osiągnięcie tych samych poziomów dane jest w znacznie węższym zakresie, a mianowicie odpowiednio 36 proc. i 67 proc. 


\section{Rozważania końcowe}

Zaprezentowane badanie dostarczyło dowodów na to, że polscy gimnazjaliści kończąc naukę na trzecim etapie kształcenia, są wyposażeni w kompetencje moralno-etyczne na różnym poziomie. Wyniki uzyskiwane przez nich w tym zakresie nie są wyłącznie pochodną ich możliwości kognitywnych, lecz również kontekstu społeczno-kulturowego. Podczas gdy uczniowie i uczennice pochodzący z domów dobrze sytuowanych z łatwością osiągają wysokie poziomy na trzech skalach kompetencji moralno-etycznych, przeważająca większość uczniów wywodzących się z mniej uprzywilejowanych środowisk, a nawet upośledzonych, ze względu na niski status społeczny i utrudniony dostęp do edukacji, sytuuje się na tych skalach na najniższych poziomach. W znacznej mierze odpowiedzialność za tę dysproporcję ponosi „pozór edukacyjny”, który w odniesieniu do lekcji etyki polega na formalnym tylko ich zakotwiczeniu w programach nauczania i planach lekcyjnych. W odróżnieniu od uczniów wywodzących się ze średniej i wyższej klasy społecznej, u których braki w zakresie wychowania i nauczania moralno-etycznego z łatwością mogą być zrekompensowane przez oddziaływania rodzinne, nastolatkowie pochodzący z rodzin wychowawczo i edukacyjnie słabo lub całkowicie niewydolnych takich możliwości nie mają. Nierzadko uczniowie ci w szkole zamiast doświadczyć wsparcia w celu zniwelowania niewątpliwych braków są pozostawieni sami sobie. Jak lekcje etyki mogą pomóc w tym zakresie, starano się uwypuklić powyżej w odniesieniu do jednej z grup gimnazjów, w której (co prawda tylko nieliczni) uczniowie brali udział w zajęciach z etyki.

\section{Bibliografia}

Benner D., Nikolova R. (red.) (2016). Ethisch-moralische Kompetenz als Teil öffentlicher Bildung. Der Berliner Ansatz zur Konstruktion und Erhebung ethisch-moralischer Kompetenzniveaus im öffentlichen Erziehungs- und Bildungssystem mit einem Ausblick auf Projekte zu ETiK-International. Paderborn-MünchenWien-Zürich: Schöningh.

Decyzja dyrektora Narodowego Centrum Nauki $z$ dnia 11.01.2010, archiwum D. Stępkowskiego.

Decyzja dyrektora Narodowego Centrum Nauki z dnia 23.01.2014, archiwum D. Stępkowskiego.

Dostępność lekcji religii wyznań mniejszościowych i lekcji etyki w ramach systemu edukacji szkolnej. Analiza i zalecenia. (2015). „Biuletyn Rzecznika Praw Obywatelskich", nr 6.

Etyka w szkole 30.09.2013. Dostępny na: https://docs.google.com/spreadsheets/d/1 MgLJrKKeYQR6hBMzaowR8SUsBUH7VvyIcnHWMrjClNk/edit?amp;usp=sh aring\&pli=1\#gid $=0$ (otwarto 12.02.2014). 
Hejnicka-Bezwińska T. (2015). Praktyka edukacyjna w warunkach zmiany kulturowej (w poszukiwaniu logiki zmian). Warszawa: Państwowe Wydawnictwo Naukowe.

Heller K.A., Perleth C. (2000). Kognitiver Fähigkeitstest für 4. bis 12. Klassen, Revision. KFT 4-12+. Göttingen: Beltz-Test.

Horowski J. (2015). Wychowanie moralne według pedagogiki neotomistycznej. Toruń: Wydawnictwo Uniwersytetu Mikołaja Kopernika.

Kotłowski K. (1976). Aksjologiczne podstawy teorii wychowania moralnego. Wrocław-Warszawa-Kraków-Gdańsk: Zakład Narodowy im. Ossolińskich.

List $z$ dnia 25.02.2010, archiwum D. Stępkowskiego.

Łobocki M. (2008). Wychowanie moralne w zarysie. Kraków: Oficyna Wydawnicza „Impuls".

Marek Z. (2005). Podstawy wychowania moralnego. Kraków: WSF-P „Ignatianum”, Wydawnictwo WAM.

Muszyński H. (1974). Wychowanie moralne w zespole. Warszawa: Wydawnictwa Szkolne i Pedagogiczne.

Orzeczenie z dnia 20 kwietnia 1993 roku, sygn. akt U 12/92. Dostępny na: http://otk. trybunal.gov.pl/orzeczenia/teksty/otkpdf/1993/U_12_92.pdf (otwarto 11.11.2015).

Piast-Szlubowski T. (2015). Etyka jako nowy przedmiot szkolny (gimnazjalny) - bilans rozwoju i perspektywy na przyszłość. W: S. Sztobryn, K. Kamiński, M. Wasilewski (red.). Pedagogika filozoficzna. T. VI: Filozofia wychowania w Europie Środkowej w kontekście uwarunkowań historycznych, społecznych, politycznych i filozoficznych. Łódź: WN TPF „Chowanna”, s. 413-425.

Recenzja 1. Dostępny na: https://osf.opi.org.pl/app/w14/recenzjeRw.do?do-pokazSekcje (otwarto 12.01.2010).

Recenzja 2. Dostępny na: https://osf.opi.org.pl/app/w14/recenzjeRw.do?do-pokazSekcje (otwarto 12.01.2010).

Rozporządzenie Ministra Edukacji Narodowej z dnia 14 kwietnia 1992 roku w sprawie warunków i sposobu organizowania nauki religii w publicznych przedszkolach i szkołach publicznych, Dz. U. Nr 36, poz. 155 z późn. zm.

Rozporządzenie Ministra Edukacji Narodowej z dnia 25 marca 2014 roku zmieniające rozporządzenie w sprawie warunków i sposobu organizacji nauki religii w publicznych przedszkolach i szkołach, Dz. U. nr, poz. 478.

Sprawa Grzelak przeciwko Polsce (skarga nr 7710/o2). Dostępny na: https:// www.google.pl/webhp? sourceid=chrome-instant\&ion $=1 \&$ espv $=2 \&$ ie $=$ UTF-8\#q=grzelak\%2oprzeciwko\%2opolsce\%2oorzeczenie (otwarto 9.11.2015).

Stępkowski D. (2015a). Poszukiwanie pedagogicznego proprium wychowania i ksztatcenia moralnego. W: S. Sztobryn, K. Kamiński, M. Wasilewski (red.). Pedagogika filozoficzna. T. VI: Filozofia wychowania w Europie Środkowej w kontekście uwarunkowań historycznych, społecznych, politycznych i filozoficznych. Łódź: WN TPF „Chowanna”, s. 303-322.

Stępkowski D. (2015b). Szkoła miejscem kształtowania kompetencji moralno-etycznej i kompetencji religijnej. „Paedagogia Christiana”, nr 1, s. 215-233. 
Suchodolski B. (1961). O program świeckiego wychowania moralnego. Warszawa: „Nasza Księgarnia”.

Uzasadnienie do decyzji dyrektora Narodowego Centrum Nauki z dnia 23.01.2014, archiwum D. Stępkowskiego.

Willems J., Schluss H., Schieder R., Benner D. (2014). Kompetencja religijna jako element kształcenia publicznego (wyniki badań empirycznych), tłum. D. Stępkowski. „Forum Pedagogiczne”, nr 1, s. 87-122.

Zieliński T.J. (2014). Nauka etyki w szkołach publicznych w ujęciu prawnym. W: J. Krukowski, P. Sobczyk, M. Poniatowski (red). Religia i etyka w edukacji publicznej. Warszawa: Wydawnictwo Uniwersytetu Kardynała Stefana Wyszyńskiego, s. 95-120.

\title{
ETIK-INTERNATIONAL STUDY IN WARSAW. HISTORY OF STUDY, RESEARCH PROBLEMS AND ANALYSIS OF RESULTS
}

\begin{abstract}
The main objective of the ETiK-International research conducted in some of the lower high schools in Warsaw and the Masovian area in 2014 was to find out if, and to what extent, Ethics lessons are an individual domain in teaching and learning in schools and how the results obtained by Polish students compare with their German and Austrian peers. Unfortunately, this objective was not fully attained.

The paper consists of three parts. The first one reconstructs the re-establishment of Religious Education in Polish schools and introduction of Ethics as an alternative subject. Next, it goes on to discuss the inconclusive efforts to carry out in Poland a study similar to the ETiK project which was conducted in Berlin. Finally, the third part describes the above mentioned ETiK International study, focusing mainly on the tool applied in it, the research problems and the results.
\end{abstract}

Keywords: moral and ethic skills, Ethics, Religious Education, empirical studies in pedagogy.

Dariusz Stępkowski - salezjanin, doktor habilitowany nauk społecznych w zakresie pedagogiki, zatrudniony na stanowisku profesora nadzwyczajnego w Uniwersytecie Kardynała Stefana Wyszyńskiego w Warszawie na Wydziale Nauk Pedagogicznych, kierownik Katedry Pedagogiki Ogólnej i Filozofii Wychowania. Zainteresowania badawcze: pedagogika ogólna, dydaktyka szkoły wyższej, teoria wychowania moralnego. Autorskie publikacje książkowe: Pedagogika ogólna i religia (2010), razem z D. Benner, A. von Oettingen, Z. Peng-Bildung-Moral-Demokratie (2015). Adres mejlowy: d.stepkowski@uksw.edu.pl.

Stanislav Ivanov - magister psychologii, zatrudniony w Institut für Bildungsmonitoring und Qualitätsentwicklung w Hamburgu (Niemcy), członek berlińskiego zespołu ETiK. Adres mejlowy: ivanstanislav@googlemail.com.

Anna Ksionek - magister socjologii, uczestnik studiów doktoranckich w Instytucie Socjologii Uniwersytetu Kardynała Stefana Wyszyńskiego w Warszawie, członek warszawskiego zespołu ETiK. Adres mejlowy: aniak_oo@go2.pl. 